\title{
Application of HPLC-DAD for the quantification of Lycorine in Galanthus elwesii Hook
}

\author{
Ahmet Emir, Ceren Emir, Buket Bozkurt, Mustafa Ali Onur, Nehir Unver Somer, \\ Gulen Irem Kaya*
}

Department of Pharmacognosy, Faculty of Pharmacy, Ege University, Bornova, Izmir, Turkey

\begin{abstract}
In the present study, a reversed-phase high-performance liquid chromatographic method has been used for the quantitative determination of lycorine in the aerial parts and bulbs of G. elwesii Hook. A simple method for the extraction of lycorine in low mass plant samples was employed utilizing pre-packed columns with diatomaceous earth (Extrelut $\left.{ }^{\circledR}\right)$. The chromatographic separation was performed using an isocratic system with a mobile phase of trifluoroacetic acid-water-acetonitrile $(0.01: 92.5: 7.5, \mathrm{v} / \mathrm{v} / \mathrm{v})$ applied at a flow rate $1 \mathrm{~mL} \mathrm{~min}^{-1}$ using diode array detector. The content of lycorine in the bulbs and aerial parts of G. elwesii collected from Demirci (Manisa) was found as 0.130 and $0.162 \%$, respectively. Additionally, in the bulbs of the specimens collected from Sogucak (Balikesir), lycorine was quantified as $0.055 \%$, whereas in the aerial parts, it was determined as $0.006 \%$. The method was validated partially with respect to system specificity, linearity, accuracy, precision, limits of detection (LOD) and quantitation (LOQ). Validation procedures displayed that the method was specific, accurate and precise.
\end{abstract}

Uniterms: Alkaloids. Amaryllidaceae. Plant extracts. High Performance Liquid Chromatography/method validation. High Perfomance Liquid Chromatography/quantitative analysis.

\section{INTRODUCTION}

Galanthus elwesii Hook. (Amaryllidaceae) is an easily recognized species with broad glaucous leaves, large flowers and bold markings on the inner segments. It has a relatively wide distribution and can be found in eastern parts of the former Yugoslavia, northern Greece, the eastern Aegean Islands, southern Ukraine, Bulgaria and Turkey. Within Turkey, this species has the widest distribution among others and naturally grows in northwestern, western and southern Anatolia (B1shop, Davis, Grımshaw, 2006; Yuzbasioglu, 2012).

Plants of the Amaryllidaceae are known to produce alkaloids with a wide range of pharmacological activities (Unver, 2007; Hoshino, 1998). Among the Amaryllidaceae alkaloids, galanthamine, is used for the treatment of mild and moderate cases of Alzheimer's disease (AD) (Howes, Perry, 2011). Lycorine, a major alkaloid found in many Amaryllidaceae species, has been shown to have

\footnotetext{
*Correspondence: G. I. Kaya. Department of Pharmacognosy. Faculty of Pharmacy. Ege University, 35100. Bornova, Izmir, Turkey. E-mail: gulen.irem.kaya@ege.edu.tr
}

a wide variety of biological activities such as antitumoral (Wang et al., 2014), antimalarial (Cedron et al., 2010), hepatoprotective (Ilavenil, Kaleeswaran, Ravikumar, 2012), antiviral (He et al., 2013), antifungal (Shen et al., 2014) and antiparasitic (Giordani et al., 2012) activities. Due to its diverse biological properties, it has been to the interest of phytochemists to determine the content of this alkaloid using various analytical techniques in Amaryllidaceous plants (Abou-Donia et al., 2007; Petruczynik et al., 2016).

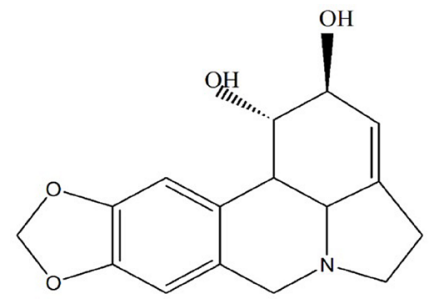

FIGURE 1 - Chemical structure of lycorine.

In the present study, during the course of our ongoing phytochemical studies on Turkish Galanthus species, aerial parts and bulbs of G. elwesii, collected 
from two different localities in Western Turkey, were quantitatively analyzed for their lycorine content by using high performance liquid chromatography (HPLC) coupled with a diode array detector (DAD). In the context of validation procedures, linearity, precision, limits of detection and quantification, accuracy, and specificity of the method were also displayed. In addition, the specimens were analyzed for their galanthamine content.

\section{MATERIAL AND METHODS}

\section{Material}

Standard sample of lycorine was previously isolated in our laboratory and authenticated by detailed spectral analysis (UV, IR, NMR, MS) (Kaya et al., 2004a). The chemical structure of lycorine was given in Figure 1. TFA (trifluoroacetic acid) (Merck), HPLC grade acetonitrile (Lab-Scan Analytical Sciences) and chromatographic grade double-distilled water were used for the HPLC analysis. Other chemicals were of analytical grade.

\section{Apparatus}

Both the analysis of the samples and the validation studies were performed on a liquid chromatographic system (Agilent 1100 series), equipped with a quaternary pump, a vacuum degasser, a thermostatted column compartment, a manual injector with $20 \mu \mathrm{L}$ loop (Rheodyne 7725i), a diode array detector (DAD) (Agilent 1200 series $)$ and a Hichrom $\mathrm{C}_{18}$ column $(250 \times 4.6 \mathrm{~mm}$, i.d., particle size $5 \mu \mathrm{m}$ ).

\section{Procedure}

Samples

Specimens of G. elwesii were collected from Sogucak (Balikesir) and Demirci (Manisa) in Western Turkey, during flowering time. The plants were identified by Prof. M. Ali Onur from the Department of Pharmacognosy, Faculty of Pharmacy, Ege University, Izmir, Turkey. Voucher samples of G. elwesii (No's 1363 and 1401) are deposited in the Herbarium of the Department of Pharmacognosy, Faculty of Pharmacy, Ege University.

\section{Preparation of samples and standard solutions}

The extraction procedure of lycorine from the plant material and preparation of standard lycorine solutions were performed according to a previously used method (Kaya et al., 2010).

\section{HPLC determination}

The extract was dissolved in $1 \mathrm{~mL} 0.1 \%$ TFA. The injection volume was $20 \mu \mathrm{L}$ and the flow rate was $1 \mathrm{~mL} /$ $\mathrm{min}$. The chromatographic run time was $50 \mathrm{~min}$. Column temperature was set at $25^{\circ} \mathrm{C}$. The chromatographic separation was achieved isocratically using a mobile phase consisted of TFA-water-acetonitrile (0.01:92.5:7.5, v/v/v) on a Hichrom $\mathrm{C}_{18}$ column and detection was carried out at $290 \mathrm{~nm}$ (Kaya et al., 2010; Mustafa, Rhee, Verpoorte, 2003). Quantitative determination was carried out by an external standard method based on peak areas.

\section{RESULTS AND DISCUSSION}

The previously proposed method (Kaya et al., 2010; Mustafa, Rhee, Verpoorte, 2003) was applied for the detection of lycorine and galanthamine plus for the quantification of lycorine in G. elwesii specimens. Under the above-stated chromatographic conditions, lycorine was resolved within approximately $9 \mathrm{~min}$. (Figure 2 and 3 ). Quantitative determination was carried out by the external standard method based on peak areas. The results of the mean values of three replicate injections of lycorine were reported in Table I. Significant variation in the amounts of lycorine was found in the analyzed samples.

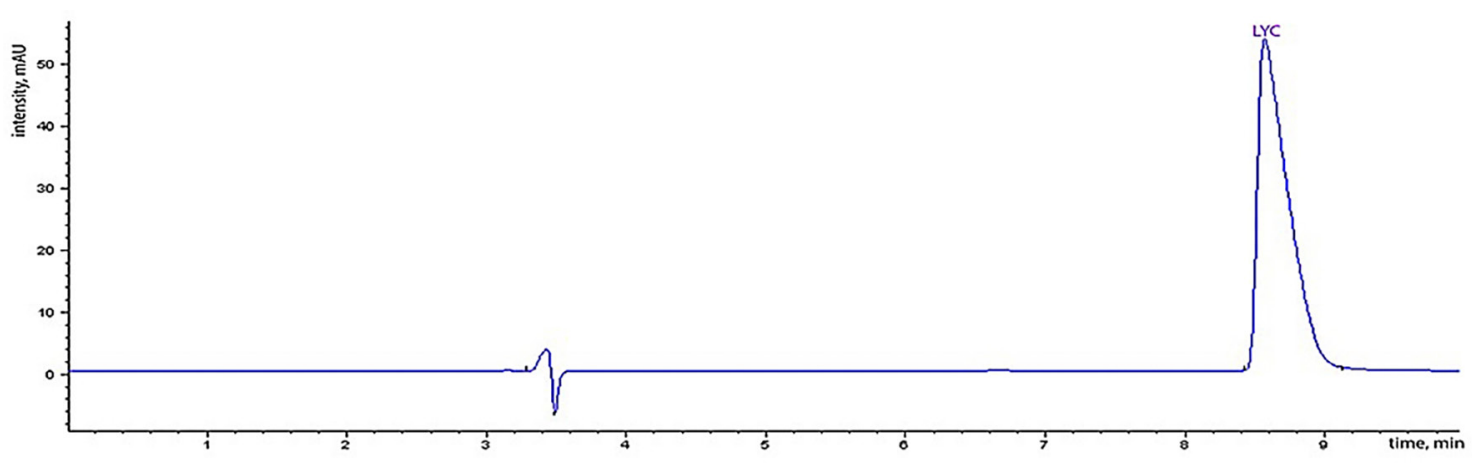

FIGURE 2 - Chromatogram of lycorine. 


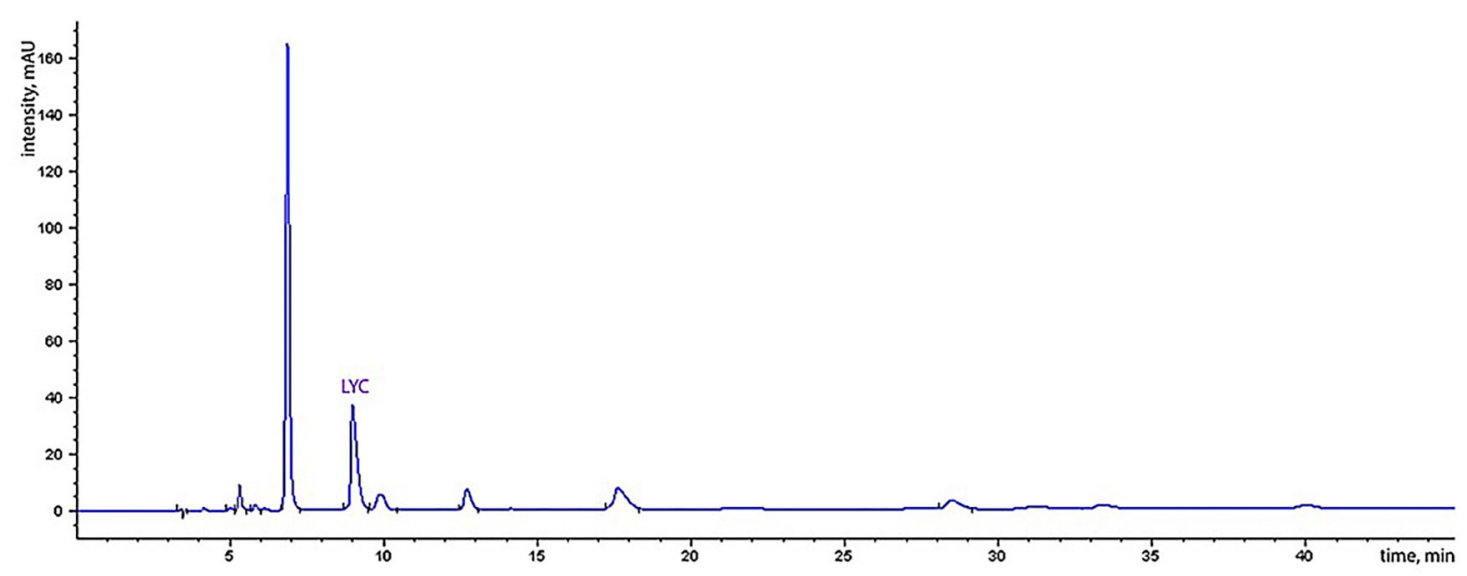

FIGURE 3 - Chromatogram of an extract of G. elwesii.

The lycorine content ranged between $0.006-0.162 \%$. The highest amount was found in the aerial parts of $G$. elwesii collected from Demirci (Manisa). Linearity, accuracy and precision studies were carried out according to the $\mathrm{ICH}$ validation guidelines on the validation of analytical procedures (ICH, 2005).

\section{Specificity}

Specificity is described as the ability to measure the analyte response in the presence of components such as impurities, degradants, matrix, etc. (ICH, 2005). The specificity of the method for the analysis of lycorine was evaluated in the presence of other components of the extracts. Peak purities of lycorine was evaluated by the acquisition of UV spectra with the DAD detector.

\section{Linearity}

Stock standard solution of lycorine was prepared by dissolving $2 \mathrm{mg}$ in $10 \mathrm{~mL} 0.1 \%$ TFA. The linearity of the method was shown by injecting seven known concentrations of the standard lycorine in the range of 2.5$200 \mu \mathrm{g} / \mathrm{mL}$. Each standard solution $(20 \mathrm{~mL})$ was injected into the column in triplicate and then the calibration curve of the analyte was obtained by plotting the peak area versus the concentration. The regression equation for lycorine was found as $y=16.17864 x-3.12657$. Excellent linearity was obtained $\left(\mathrm{r}^{2}=0.99997\right)$ exhibiting a good correlation between the alkaloid concentration and the peak area.

\section{Accuracy}

Accuracy may be defined as the agreement between the found value and true value of the reference material and can be presented as a percent recovery. Standard addition analysis was performed for the recovery of the method. Three known amounts of the individual standard were added to sample solutions and the mixtures were analyzed by the same method used in the analysis of lycorine in the plant samples. Recovery assay was carried out by spiking three different known concentrations of lycorine into the sample solutions prior to extraction. The mean extraction recovery of lycorine was found as in the range of $94.24-100.60 \%$. The results of the experiments are given in Table I.

\section{Precision}

The precision of the method was evaluated by studying intra-day and inter-day variations. Intra-day precision was determined by injecting solutions of seven different concentrations of standard lycorine $(2.5,5,10$, $25,50,100,200 \mu \mathrm{g} / \mathrm{mL}$ ) in triplicate on the same day. Inter-day precision was calculated by performing the same procedure on two different days. The results of the precision analysis of lycorine are summarized in Table II. RSD was found to be always less than $2.0 \%$ when the analysis was performed at seven different concentrations.

\section{Limit of detection and limit of quantification}

Limit of detection (LOD) and limit of quantification

TABLE I - Statistical data showing recovery studies of lycorine $(n=3)$

\begin{tabular}{lccccc}
\hline & in sample $(\boldsymbol{\mu g} / \mathbf{m L})$ & Spiked $(\boldsymbol{\mu g} / \mathbf{m L})$ & found $(\boldsymbol{\mu g} / \mathbf{m L})$ & recovery, $\%$ & RSD, $\%$ \\
\hline Lycorine & 0.033 & 0.0165 & 0.0249 & 100.60 & 0.725 \\
& 0.033 & 0.033 & 0.0311 & 94.24 & 0.735 \\
& 0.033 & 0.066 & 0.0498 & 100.60 & 1.737 \\
\hline
\end{tabular}


TABLE II - Intra-day and inter-day precision of the method

\begin{tabular}{lccc}
\hline Compound & Amount $(\boldsymbol{\mu g} / \mathbf{m L})$ & Intra-day precision $(\mathbf{R S D}, \mathbf{\%})$ & Inter-day precision $(\mathbf{R S D}, \mathbf{\%})$ \\
\hline Lycorine & 2.5 & 1.27 & 1.78 \\
5 & 1.76 & 1.2 \\
10 & 1.54 & 1.34 \\
25 & 0.77 & 1.24 \\
50 & 1.77 & 1.77 \\
100 & 0.39 & 0.23 \\
& 200 & 0.17 & 0.34 \\
\hline
\end{tabular}

were evaluated based on the signal-to-noise ratio $(\mathrm{S} / \mathrm{N})$ of 3 and 10, respectively. LOD and LOQ were experimentally determined by 10 injections of lycorine. The LOD and the LOQ of the analyte were calculated as $0.0423 \mu \mathrm{g} / \mathrm{mL}$ and $0.14921 \mu \mathrm{g} / \mathrm{mL}$ respectively.

\section{CONCLUSION}

Comprising a part of our phytochemical studies on Galanthus species of Turkish origin, the present study was undertaken to evaluate the lycorine and galanthamine contents of two Galanthus elwesii specimens naturally growing in Western Turkey. As a result, lycorine was determined both in the aerial parts and bulbs of these specimens, however galanthamine was not detected in any of the plant samples. The employed method has several advantages including simple and rapid sample preparation, requirement of a small amount of plant material, and a simple mobile phase. The method was also validated with respect to linearity, intra and inter-day precision, recovery, limits of detection and quantification. Validation studies showed that the method could be successfully used to determine lycorine in G. elwesii samples, which provided an efficient and reliable method for the quality control of G. elwesii. G. elwesii specimens collected from different localities in Turkey have been investigated for their content of lycorine and galanthamine in previous studies (Kaya et al., 2004b; Celik-Sarier, 2002; Kaya, Gozler, 2003; Muhtar, Sener, 1996; Kaya et al., 2014). The results of these studies together with the results of the present study are summarized in Table III.

The results obtained in the present study differ

TABLE III - Lycorine and galanthamine content of Galanthus elwesii from different localities

\begin{tabular}{|c|c|c|c|}
\hline Localities & Plant parts & Lycorine, \% & Galanthamine, $\%$ \\
\hline \multirow{2}{*}{ Soğucak (Balıkesir) ${ }^{\mathrm{a}}$} & Bulbs & $0.055^{\mathrm{a}}$ & ND $^{a b}$ \\
\hline & Aerial parts & $0.006^{\mathrm{a}}$ & ND ${ }^{a b}$ \\
\hline \multirow{2}{*}{ Demirci (Manisa) ${ }^{\mathbf{a}}$} & Bulbs & $0.130^{\mathrm{a}}$ & ND ${ }^{a b}$ \\
\hline & Aerial parts & $0.162^{\mathrm{a}}$ & ND $^{\mathbf{a b}}$ \\
\hline \multirow{2}{*}{ Yamanlar (İzmir) (Kaya et al., 2004b; Celik-Sarier, 2002) } & Bulbs & $\mathrm{ND}^{\mathbf{b}}$ & $\mathrm{ND}^{\mathbf{b}}$ \\
\hline & Aerial parts & $\mathrm{ND}^{\mathbf{b}}$ & $\mathrm{ND}^{\mathbf{b}}$ \\
\hline \multirow{2}{*}{ Akdag-Karaburun (İzmir) (Kaya, Gozler, 2003) } & Bulbs & $0.004-0.007$ & $0.007-0.008$ \\
\hline & Aerial parts & $0.001-0.013$ & $0.013-0.026$ \\
\hline Akseki (Antalya) (Muhtar, Sener, 1996) & Bulbs & 0.011 & Not studied \\
\hline \multirow{2}{*}{ Cimi Village (Antalya) (Kaya et al., 2014) } & Bulbs & $\mathrm{ND}^{\mathrm{b}}$ & 0.042 \\
\hline & Aerial parts & $\mathrm{ND}^{\mathrm{b}}$ & 0.346 \\
\hline \multirow{2}{*}{ Ibradi (Antalya) (Kaya et al., 2014) } & Bulbs & 0.005 & 0.095 \\
\hline & Aerial parts & ND & 0.287 \\
\hline \multirow{2}{*}{ Kayrak (Mersin) (Kaya et al.,2014) } & Bulbs & 0.015 & $\mathrm{ND}^{\mathrm{b}}$ \\
\hline & Aerial parts & $\mathrm{ND}^{\mathbf{b}}$ & $\mathrm{ND}^{\mathrm{b}}$ \\
\hline
\end{tabular}

${ }^{\mathbf{a}}$ The results of the present study; ${ }^{\mathbf{b}} \mathrm{ND}$ : Not detected 
significantly from the results of previous studies on Galanthus elwesii (Table III). This could be caused by endogenous and exogenous factors. Karyological investigations on Turkish Galanthus populations have been made by several researchers (Şenel, Ozkan, Kandemir, 2002; Zeybek, 1988; Zeybek, Sauer, 1994) and these studies have revealed a polymorphism among different karyotypes and SAT - chromosomes which were reported to be important in the variation (Kandemir, 2010). Earlier reports showed that the concentration of alkaloids vary in great amount in different Amaryllidaceae plants with the seasonal growth (Katoch et al., 2012; Tram et al., 2002). In addition, it has been documented that a relationship existed between the alkaloid content of an Amaryllidaceous species Leucojum aestivum L. and the chemical composition of the soil (Gorinova et al., 1993). Therefore, the variations of the alkaloid content in $G$. elwesii specimens may be influenced by several factors including polymorphism, collection site and time.

\section{ACKNOWLEDGMENTS}

This study was financially supported by the Ege University Research Fund (Project No: 09/ECZ/037) and partially supported by TUBITAK (104T272) and EBILTEM (2007/BIL/007).

\section{REFERENCES}

ABOU-DONIA, A.H.; TOAIMA, S.M.; HAMMODA, H.M.; SHAWKY, E. New rapid validated HPTLC method for the determination of lycorine in Amaryllidaceae plants extracts. Chromatographia, v.65, p.497-500, 2007.

CEDRON, J.C.; GUTIERREZ, D.; FLORES, N.; RAVELO, A.G.; ESTEVEZ-BRAUN, A. Synthesis and antiplasmodial activity of lycorine derivatives. Bioorg. Med. Chem., v.18, p.4694-701, 2010.

CELIK-SARIER, D. Pharmacognostical studies on Galanthus elwesii Hook: growing around Karagöl, Yamanlar, Izmir. Izmir, 2002. MSc Thesis, Ege University.

BISHOP, M.; DAVIS, A.P.; GRIMSHAW, J.P. Snowdrops: a monograph of cultivated Galanthus. Cheltenham: Griffin Press, 2006. p.32-36.
HE, J.; QI, W.; WANG, L.; TIAN, J.; JIAO, P.; LIU, G.; YE, W.; LIAO, M. Amaryllidaceae alkaloids inhibit nuclear-tocytoplasmic export of ribonucleoprotein (RNP) complex of highly pathogenic avian influenza virus H5N1. Influenza Other Respir. Viruses, v.7, n.6, p.922-931, 2013.

HOSHINO, O. The Amaryllidaceae alkaloids. In: CORDELL, G.A. (ed). The alkaloids: chemistry and physiology. San Diego: Academic Press, 1998. p.323-424.

HOWES, M.J.; PERRY, E. The role of phytochemicals in the treatment and prevention of dementia. Drug Aging, v.28, p.439-468, 2011.

GIORDANI, R.B.; JUNIOR, C.O.R.; ANDRADE, J.P.; BASTIDA, J.; ZUANAZZI, J.A.S.; TASCA, T.; ALMEIDA, M.V. Lycorine derivatives against Trichomonas vaginalis. Chem. Biol. Drug. Des., v.80, p.129-133, 2012.

GORINOVA, N.I.; ATANASSOV, A.I.; STOJANOV, D.V.; TENCHEVA, J. Influence of chemical composition of soils on the galanthamine content in Leucojum aestivum. J. Plant Nutr., v.16, n.9, p.1631-1636, 1993.

\section{INTERNATIONAL CONFERENCE ON HARMONISATION.} ICH. Quality Guidelines. Q2 (R1). Validation of analytical procedures: text and methodology, Nov. 2005. Available from: <http://www.ich.org/products/guidelines/quality/ article/quality-guidelines.html $>$. Access on: abrev. Month day, year.

ILAVENIL, S.; KALEESWARAN, B.; RAVIKUMAR, S. Protective effects of lycorine against carbon tetrachloride induced hepatotoxicity in Swiss albino mice. Fundam. Clin. Pharmacol., v.26, n.3, p.393-401, 2012.

KANDEMIR, N. A karyological investigation on the two varieties of Galanthus fosteri Baker (Amaryllidaceae). Biol. Diversity Conserv., v.3/2, p.20-25, 2010.

KAYA, G.I.; GOZLER, T. Quantitative evaluation of the specimens of Galanthus elwesii. J. Fac. Pharm. Gazi, v.20, p.71-78, 2003.

KAYA, G.I.; UNVER, N.; GOZLER, B.; BASTIDA, J. (-)-Capnoidine and (+)-bulbocapnine from an Amaryllidaceae species, Galanthus nivalis subsp. cilicicus. Biochem. Syst. Ecol., v.32, p.1059-1062, 2004 a. 
KAYA, G.I.; FILLIK, A.; HISIL, Y.; UNVER, N. High pressure liquid chromatographic analysis of lycorine in four Galanthus species growing in Turkey. Turk J. Pharm. Sci., v.1, p.105-114, 2004b.

KAYA, G.I.; CICEK, D.; SARIKAYA, B.; ONUR, M.A.; UNVER-SOMER, N. HPLC - DAD analysis of lycorine in Amaryllidaceae species. Nat. Prod. Commun., v.5, n.6, p.873-876, 2010.

KAYA, G.I.; POLAT-CICEK, D.; EMIR, A.; SARIKAYABOZKURT, B.; ONUR, M.A.; UNVER-SOMER, N. Quantitative determination of galanthamine and lycorine in Galanthus elwesii by HPLC-DAD. Turk J. Pharm. Sci., v.11, p.107-112, 2014.

KATOCH, D.; KUMAR, S.; KUMAR, N.; SINGH, B. Simultaneous quantification of Amaryllidaceae alkaloids from Zephyranthes grandiflora by UPLC-DAD/ESI-MS/ MS. J. Pharm. Biomed. Anal., v.71, p.187-192, 2012.

MUHTAR, F.; SENER, B. Evaluation of Amaryllidaceae plants exported from Turkey regarding lycorine. In: MEETING ON PLANT CRUDE DRUGS, 11, Ankara, 1996. Proceedings. Ankara, 1996. p.384-388.

MUSTAFA, N.R.; RHEE, I.K.; VERPOORTE, R. Rapid method for determination of galanthamine in Amaryllidaceae plants using HPLC. J. Liq. Chromatogr. Relat. Technol., v.26, n.19, p.3217-3233, 2003.

PETRUCZYNIK, A.; MISIUREK, J.; TUZIMSKI, T.; USZYŃSKI, R.; SZYMCZAK, G.; CHERNETSKYY, M.; WAKSMUNDZKA-HAJNOS, M. Comparison of different HPLC systems for analysis of galanthamine and lycorine in various species of Amaryllidaceae family. $J$. Liq. Chromatogr. Relat. Technol., v.39, p.574-579, 2016.
SHEN, J.; RUAN, Y.; REN, W.; MA, B.; WANG, X.; ZHENG, C. Lycorine: a potential broad-spectrum agent against crop pathogenic fungi. J. Microbiol. Biotechnol., v.24, p.354-358, 2014.

SENEL, G.; OZKAN, M.; KANDEMIR, N. A Karyological investigation on some rare and endangered species of Amaryllidaceae in Turkey. Pak. J. Bot., v.34, n.3, p.229235, 2002.

TRAM, N.T.N.; MITOVA, M.; BANKOVA, V.; HANDJIEVA, N.; POPOV, S.S. GC-MS of Crinum latifolium L. alkaloids. Z. Naturforsch., v.57, p.239-242, 2002.

UNVER, N. New skeletons and new concepts in Amaryllidaceae alkaloids. Phytochem. Rev., v.6, p.125-135, 2007.

WANG, P.; YUAN, H.; ZHANG, X.; LI, Y.; SHANG, L.; YIN, Z.; Novel lycorine derivatives as anticancer agents: synthesis and in vitro biological evaluation. Molecules, v.19, p.2469-2480, 2014.

YUZBASIOGLU, S. Morphological variations of Galanthus elwesii in Turkey and difficulties on identification. Bocconea, v.24, p.335-339, 2012.

ZEYBEK, N. Taxonomical investigations on Turkish snowdrops (Galanthus L.). Turk J Botany., v.12, p.89-103, 1988.

ZEYBEK, N.; SAUER, E. Turkish snowdrops I (Beitrag zur Kenntnis der Türkischen Schneeglöckhen) (Galanthus L.) I. Ornamental Plants. İzmir: Agriculture and Industry Press, 1994. p.29-32.

Received for publication on $27^{\text {th }}$ March 2015 Accepted for publication on $25^{\text {th }}$ October 2016 